\title{
RESENHA: SILVA, A. C. TEORIA E MÉTODO EM GEOGRAFIA. BORRADOR, Nº 1, TEORIA E MÉTODO EM GEOGRAFIA, ASSOCIAÇÃO DOS GEÓGRAFOS BRASILEIROS - SÃO PAULO
}

Uilmer Rodrigues Xavier da Cruz

Mestre em Geografia no Programa de Pós-Graduação da Universidade do Estado do Rio de Janeiro (UERJ). Professor de Geografia da Secretaria de Educação de Minas Gerais

E-mail: uilmer@ufmg.br

O autor bacharelou-se em Ciências Sociais pela Faculdade de Filosofia, Ciências e Letras da Universidade de São Paulo e obteve o título de doutor em geografia pelo Departamento de Geografia da Universidade de São Paulo. Na USP, foi professor titular e se tornou livre-docente com a tese "A Metrópole Ampliada e o Bairro Metropolitano, O Caso de São Paulo, O Bairro da Consolação". Levando uma vida eclética, foi balconista, entregador, militante comunista e militante na Associação dos Geógrafos Brasileiros, foi eleito presidente da AGB em Salvador, nos anos 1990-1992, sendo responsável inicial pela reestruturação da AGB nos anos 1990. Trabalhou por vários anos no Programa de Pós-Graduação em Geografia da Faculdade de Ciências e Tecnologia, UNESP, de Presidente Prudente. Realizou dois encontros nacionais, o $2^{\circ}$ Fala Professor de 1991 na USP e o $9^{\circ}$ ENG na UNESP de Prudente em 1992. Nos anos 1990, sua linha de pesquisa foi: "0 Futuro do Homem e do Espaço na Década de 90.

O autor nos traz um texto construído para uma reunião, em que traz as contribuições de dezesseis teses e fala sobre a teoria e o método da pesquisa em Geografia do ponto de vista da consciência teórica, em que trata do movimento do pensamento em relação ao tema proposto, que se inicia com a totalidade, ou como o autor prefere denominar, subtotalidade. Num segundo momento se realiza como projeto e num terceiro momento se realiza como mapa.

Na primeira tese, A geografia é o modo de conhecimento do mundo em que vivemos e sobre o qual elaboramos teorias, o autor salienta que a categoria mundo referese, então, ao espaço existente e ao espaço humano, construído pelo homem e que só por ele é inteligível. O que está sendo exposto mostra, por isso, que é impossível caracterizar a Geografia a não ser por meio da própria teoria. 
$\mathrm{Na}$ segunda tese, Essas teoria são ou comportamentos científico do real, ou ideologias, ele afirma que a teoria científica, como falsa consciência, é o momento de negação da consciência verdadeira, que se põe como devir da contradição. Ou seja, a falsa consciência nega a consciência verdadeira e é a ideologia do erro.

$\mathrm{Na}$ terceira tese, $O$ conhecimento científico do real implica na realização prévia da crítica das ideologias, a falsa consciência se pões como incapacidade de apreensão do real. Essa incapacidade não é dada, mas surge com a transformação da consciência verdadeira em ideologia. A crítica da ideologia significa, então, a descoberta do erro, isto é, a sua identificação em teoria falsa.

Na quarta tese, A crítica das ideologias só alcança significado científico se reproduz o movimento do ser em seu devir, afirma que reproduzir o movimento do ser em devir é apreender conceitualmente seu conteúdo, que será transformado em conhecimento, desde que seja liberto de suas barreiras ideológicas.

Na quinta tese, Reproduzir o movimento do ser em seu devir é descobrir-lhe as determinações essenciais, afirma que descobrir as determinações essenciais é de alguma coisa é reproduzir-lhe a práxis.

$\mathrm{Na}$ sexta tese, As determinações essenciais geográficas são o espaço e seu domínio de posse, o espaço geográfico é o espaço do mundo habitado pelo homem, mas desde que tenha seu domínio de posse.

Na sétima tese, A especificidade do geógrafo resulta, então, em que a ideologia em geografia confunde-se com o cotidiano das formas e relações, afirma que a consciência do geógrafo é um modo de conhecimento científico, que se põe como o significado de paisagem, resultante da apropriação das formas de relações.

$\mathrm{Na}$ oitava tese, As formas de relações são percebidas como espaço a produzir, espaço em produção e espaço produzido, ressalta que a produção do espaço não pode dar-se senão como espaço existente que determina o espaço a produzir, o espaço em produção e o espaço produzido.

Na nona tese, O espaço produzido, resultado final do processo, é, na verdade, o verdadeiro ponto de partida como trabalho que se produz, afirma que a produção do espaço só ocorre a partir do espaço já existente, em que a consciência verdadeira, na produção do espaço, já contém as formas e relações que deseja produzir, como projeto. 
Na décima tese, É uma característica da geografia que o espaço que se produz, só o pode ser, a partir do próprio espaço existente, já produzido pelo trabalho, afirma que o projeto se apropria das formas e relações existentes e as transforma na construção de um espaço novo.

Na décima primeira tese, Desvendar o significado das formas e relações é o modo de por-se o método geográfico através da mediação da pesquisa, nos contribui afirmando que o método geográfico é o pensamento em movimento que apreende as formas e relações do mundo em que vivemos.

$\mathrm{Na}$ décima segunda tese, O espaço produzido é um "a priori” que só pode ser compreendido em seu significado "a posteriori", nos diz que a consciência o é da realidade e não o contrário e esta descoberta se dá pelo método, com a mediação da pesquisa.

$\mathrm{Na}$ décima terceira tese, Não obstante, o conhecimento científico, desde logo se põe como o modo ideológico dessa compreensão, afirma que toda a consciência é ideológica, tanto a falsa como a verdadeira.

Na décima quarta tese, Para utilizar o conhecimento científico é preciso, então, por-se como sujeito consciente do ato de conhecer, afirma que o ato de conhecer é especificidade do ser enquanto ser intelectual, na produção do trabalho teórico.

Na décima quinta tese, A consciência do devir mostra-se, então, como parte do método, que o acompanha no movimento do pensar as formas e relações, o autor nos diz que a teoria e o método de pesquisa são parte de um movimento do pensamento, que avança em direção à compreensão do vir a ser e o apreende como formas e relações em processo de efetivar-se como espaço produzido novo.

$\mathrm{Na}$ décima sexta tese, A verdade do conhecimento aparece, por fim, como a prática teórica correta, que tem na posição de classe o parâmetro do encontro do significado da teoria prática, que, ao orientar a ação, mostra-se como prática teórica. Por isso, a verdade é uma verdade de classe, que varia no tempo e no espaço de sua realização como futuro socialmente desejado.

É uma leitura que exige conhecimentos prévios para ser entendida, uma vez que as conclusões emergem a partir uma síntese realizada pelo autor há dez anos e utiliza conceitos próprios da geografia. O texto tem por objetivo trazer um diálogo com estudantes universitários, pesquisadores, cientistas e profissionais da área para que os 
Resenha: SILVA, A. C. Teoria e método em geografia. Borrador, $\mathbf{n}^{\circ}$ 1, Teoria e método em geografia, Associação dos Geógrafos Brasileiros - São Paulo

mesmos possam refletir, pesquisar, discutir ou se posicionar criticamente sobre o assunto abordado.

Recebido em 07/04/2019.

Aceito para publicação em 21/05/2019. 